\title{
Original Research \\ The effect of patient satisfaction with pharmacist consultation on medication adherence: an instrumental variable approach
}

\author{
Ning Yan GU, Yunwei GAI, Joel W. HAY. \\ Received (first version): 21-Jul-2008 Accepted: 24-Oct-2008
}

\begin{abstract}
${ }^{*}$
There are limited studies on quantifying the impact of patient satisfaction with pharmacist consultation on patient medication adherence.

Objectives: The objective of this study is to evaluate the effect of patient satisfaction with pharmacist consultation services on medication adherence in a large managed care organization.

Methods: We analyzed data from a patient satisfaction survey of 6,916 patients who had used pharmacist consultation services in Kaiser Permanente Southern California from 1993 to 1996. We compared treating patient satisfaction as exogenous, in a single-equation probit model, with a bivariate probit model where patient satisfaction was treated as endogenous. Different sets of instrumental variables were employed, including measures of patients' emotional well-being and patients' propensity to fill their prescriptions at a non-Kaiser Permanente (KP) pharmacy. The SmithBlundell test was used to test whether patient satisfaction was endogenous. Over-identification tests were used to test the validity of the instrumental variables. The Staiger-Stock weak instrument test was used to evaluate the explanatory power of the instrumental variables. Results: All tests indicated that the instrumental variables method was valid and the instrumental variables used have significant explanatory power. The single equation probit model indicated that the effect of patient satisfaction with pharmacist consultation was significant $(p<0.010)$. However, the bivariate probit models revealed that the marginal effect of pharmacist consultation on medication adherence was significantly greater than the single equation probit. The effect increased from $7 \%$ to $30 \%(p<0.010)$ after controlling for endogeneity bias.

Conclusion: After appropriate adjustment for endogeneity bias, patients satisfied with their pharmacy services are substantially more likely to adhere to their medication. The results have important policy implications given the increasing focus on the roles of pharmacists and regulatory changes in professional scope of practice.
\end{abstract}

Keywords: Patient Satisfaction. Patient Compliance. Pharmacists. United States.

Ning Yan GU. MS. University of Southern California, Los Angeles, CA (United States).

Yunwei GAI. PhD. Babson College, Babson Park, MA, (United States).

Joel W. HAY. PhD. University of Southern California, Los Angeles, CA (United States).

\author{
EFECTO DE LA SATISFACCIÓN DEL \\ PACIENTE CON LA CONSULTA DEL \\ FARMACÉUTICO SOBRE LA ADHERENCIA \\ A LA MEDICACIÓN: ABORDAJE DE \\ VARIABLE INSTRUMENTAL
}

\section{RESUMEN}

Hay pocos estudios que cuantifiquen el impacto de la satisfacción del paciente con la consulta farmacéutica sobre la adherencia a la medicación. Objetivos: El objetivo de este estudio es evaluar el efecto de la satisfacción del paciente con los servicios de consulta farmacéutica sobre la adherencia a la medicación en una gran organización de gestión de cuidados. Métodos: Analizamos datos de un cuestionario de satisfacción de 6.916 pacientes que habían usado consultas farmacéuticas de la Kaiser Permanente Southern California desde 1993 a 1996. Comparamos, tratando la satisfacción del paciente como exógena, en un modelo probit de una ecuación, con un modelo proibit bivariado donde la satisfacción se trató como endógena. Se utilizaron diferentes conjuntos de variables, incluyendo medidas del bienestar emocional de los pacientes y propensión de los pacientes a adquirir sus medicamentos en una farmacia no Kaiser Permanente (KP). Se usó el test Smith-Blundell para probar si la satisfacción del paciente era endógena. Se usaron test de sobre-identificación para probar la validez de las variables instrumentales. El instrumento débil de StaigerStock fue utilizado para evaluar el poder explicativo de las variables instrumentales. Resultados: Todos los métodos indicaron que el método de variables instrumentales utilizado tuvo poder explicativo. El modelo probit de una ecuación indicó que el efecto de la satisfacción del paciente con la consulta farmacéutica fue significativo $(p<0,010)$. Sin embargo, el modelo probit bivariado revela que el efecto marginal de la consulta farmacéutica en la adherencia a la medicación fue significativamente mayor que en probit de una ecuación. El efecto se incrementó del $7 \%$ al $30 \%(\mathrm{p}<0,010)$ después de controlar el sesgo de endogenicidad.

Conclusión: Después del adecuado ajuste del sesgo de endogenicidad, los pacientes satisfechos con los servicios de sus farmacias tiene sustancialmente más probabilidad de cumplir su medicación. Los resultados tienen importantes implicaciones políticas dado el creciente enfoque en los papeles del farmacéutico y los cambios reglamentarios en el ámbito del ejercicio profesional. 
Palabras clave: Satisfacción del paciente. Cumplimiento del paciente. Farmacéuticos. Estados Unidos.

\section{INTRODUCTION}

In recent years, there has been an increasing focus on the evolution of the role of the pharmacists from traditional drug dispensing to a more active and participative role in risk assessment, risk management, and other medication related consultation activities. ${ }^{1-6}$ State and federal health care programs have required ambulatory care pharmacies to provide pharmacist consultation to Medicaid patients with new or changed prescriptions. ${ }^{1}$ A large number of State Pharmacy Boards have added similar pharmacy consultation requirements for other patient groups. After passage of the 2003 Medicare Modernization Act, pharmacists can be compensated for providing therapy management to Medicare beneficiaries who are at risk for potential medication problems such as diabetes, asthma, hypertension, and congestive heart failure or multiple prescriptions that need appropriately used to optimize therapeutic outcomes and to reduce the risk of adverse events, including adverse drug interactions. ${ }^{2}$ Previous studies have found generally favorable evidence for pharmacist consultation services on various outcomes such as patient medication adherence ${ }^{7}$, reduction in hospital admission, mortality, overall health care costs ${ }^{8,9}$, as well as clinical benefits particular in chronic conditions. ${ }^{10-14}$

The aforementioned studies treat whether or not patients are given pharmacist consultation as the control variable. Providing services, however, is just one aspect. Patient satisfaction with pharmacist consultation is another important aspect of medication management. Patient satisfaction has emerged as one of the most important factors in medical care because of its relationship with healthcare outcomes. Hospitals, physicians and insurance companies have a long tradition of tracking and analyzing patient satisfaction. According to the review by Aharony \& Strasser (1993), satisfied patients are more likely to 1) continue using health care services 2) maintain a relationship with a specific health care provider 3 ) comply with medical regimens (including medications) 4) participate in their own treatment and 5) cooperate with their health care providers. ${ }^{15}$

Measuring and analyzing patient satisfaction with pharmacist consultation is a relatively new development. Some researchers hypothesize that increased patient satisfaction with pharmacist consultation would bring financial and clinical benefits for both pharmacists and patients. ${ }^{16-19}$ However, there has not yet been empirical evidence to support this hypothesis. The focus of this study is to assess how patient satisfaction with pharmacist consultation affects medication adherence. Several methodological difficulties have discouraged research associating patient satisfaction with patient medication adherence. One problem is the omitted variable bias. Besides patient satisfaction with pharmacist consultation, patients' medication adherence depends on complex interactions of medical, medication, personal, and economic factors. $^{20}$ Some factors such as personal information including memory, overall intellectual ability, organization skills, and health literacy cannot be easily measured and consequently are often omitted in surveys. These factors affect medication adherence as well as patient satisfaction with pharmacist consultation. Without accounting for these omitted factors, the estimated outcomes effect of patient satisfaction with pharmacist consultation will be biased. Due to the complex correlations of these omitted variables with patient satisfaction and medication adherence, we cannot conclude the direction of the potential bias.

The second problem is the possible reverse causality between patient satisfaction and medication adherence. Satisfied patients are more likely to have better healthcare outcomes. But patients who have improved healthcare outcomes are more likely to evaluate their healthcare providers, (e.g., physicians and pharmacists) more favorably. This reversed causality could be more prevalent in surveys when patients are asked to rate their healthcare providers retrospectively. Because of the reversed causality problem, patient satisfaction with pharmacist consultation is an endogenous variable, i.e. the causality is not one way from satisfaction to adherence but rather the two mutually affecting each other, and similar to omitted variable bias, it can lead to biased estimates of the effect of patient satisfaction on medication adherence.

In absence of clinical trials to control for all variables in the models, the instrumental variables method can be used to correct for the potential biases induced by endogeneity that confound observational studies. $^{21-26}$ This technique was popularized in health care services in early 90's by McClellan and Newhouse. ${ }^{21-22}$ When good instrumental variables can be identified, the instrumental variable method is a useful and robust method to evaluate the effectiveness of an intervention that is potentially confounded by unobservable factors.

We hypothesize that a conventional single-equation model, which ignores endogeneity bias, underestimates the magnitude of effectiveness of patient satisfaction with pharmacist consultation on medication adherence. The unbiased estimate of the effect of patient satisfaction with pharmacist consultation on patient medication adherence will only be manifested through proper adjustment for this potential endogeneity bias.

\section{METHODS}

\section{Data}

A retrospective analysis using data from the Kaiser Permanente (KP) pharmacist consultation intervention survey from 1993 to 1996 was 
conducted. Details of study design and implementation have been described elsewhere. ${ }^{3,27}$ Patient self-reported data on medication adherence collected at the completion year was used, adjusted for the baseline demographic characteristics and health status. The study sample includes patients who underwent the pharmacist consultation intervention (California-mandated patient consultation to patients with new or changed prescriptions, instructions for use, relevant warnings and precautions, storage requirements, and the importance of compliance) and had completed survey responses on their medication behaviors. 6,916 patients $(92 \%$ of the total sample) met the inclusion criteria. The large sample size in this study fulfilled the database requirement for instrumental variable estimation. $^{21}$

\section{Variables}

The primary outcome measure was the patient selfreported medication adherence. This was constructed from a set of four binary (1=yes/2=no) questions regarding patients' medication use: 1) whether or not patient had problems remembering to use medication 2) did the patient stop medication when they felt better 3 ) did the patient forget medication when away from home 4) did the patient stop medication when they felt worse. If a patient answered yes to all four questions, i.e. worst medication adherence, the minimum score was 4 . On the other hand, the score was 8 , for the best medication adherence. We constructed a dichotomous single dependent variable based on the univariate analysis on the summated score. About $4,335(62.7 \%)$ patients were above the summated median score of 7 and coded as adherent patients. Although there are pros and cons associated with patient self-reported surveys ${ }^{8,28}$, recent research has shown that these measures have a strong to moderate correlation with objective measures such as pharmacy records, insurance claims and electronic monitoring. ${ }^{29-31}$

The endogenous regressor, patient satisfaction, was also constructed dichotomously from the survey question concerning patient general satisfaction with pharmacist consultation services, which used a rating scale with four response categories that ranged from very satisfied $(=1)$ to very dissatisfied $(=4)$. About 4,469 $(64.6 \%)$ patients reported to be very satisfied with pharmacist consultation services and were assigned a binary code of 1 and, 0 was assigned to patients responded otherwise.

A total of 3 instrumental variables were identified from the data. Two were indicative of patients' emotional well-being and personality by questioning patient whether or not $\mathrm{s} /$ he was a happy or a calm person. Rating scale categories that ranged from all of the time $(=1)$ to none of the time $(=6)$ were used on these questions. It has been suggested that patients' personality or emotional status directly affect their report of satisfaction. ${ }^{32,33}$ Another instrumental variable was indicative of patients' propensity to fill their prescriptions at a non-KP pharmacy, which was selected to indicate the amount of workload at a KP pharmacy. The data revealed that $90.6 \%$ of the prescriptions were filled at KP pharmacies. We acknowledge that a patient may choose a non-KP pharmacy for reasons that are not specifically related to patient satisfaction, such as distance, but the propensity to use non-KP pharmacies is inversely related with patient satisfaction with KP pharmacy services. Whether this variable is a valid instrument is an empirical and testable issue. The 3 instrumental variables were included separately as well as in different combinations. Additional covariates used in the model included patients' age, gender, race, marital status, education levels, working status and current health status indicated by self-reported disease conditions. Detailed definitions and sample distributions are included in table 1. Further, we assume that whether or not a patient has clear understanding on the directions for how to take the medication prescribed may have a direct effect on his/her medication adherence. Hence, a binary question concerning whether or not the pharmacist consultation service involved giving instructions on "how to take medication" was included in the model. An earlier study has suggested that questions concerning the directions of medication intake are of importance for eliciting more accurate information from the patient. ${ }^{20}$

\begin{tabular}{|c|c|}
\hline $\begin{array}{l}\text { Table 1: Demographic Characteristic } \\
\text { Population }(n=6916)\end{array}$ & of the Study \\
\hline Continuous Variables & Mean (SD) \\
\hline Age & $\begin{array}{c}50.98 \\
(15.64)\end{array}$ \\
\hline Categorical Variables & $\%$ \\
\hline Gender (\% Female) & 63.81 \\
\hline Race (\%) & \\
\hline $\begin{array}{l}\text { White } \\
\text { Black }\end{array}$ & $\begin{array}{l}58.28 \\
22.08\end{array}$ \\
\hline Latino/Hispanic & 12.21 \\
\hline Asian & 6.85 \\
\hline American Indian/Other & 0.58 \\
\hline Marital Status (\%) & \\
\hline Married & 65.05 \\
\hline Single & 13.11 \\
\hline Divorced & 12.27 \\
\hline Widowed & 6.87 \\
\hline Separated & 2.70 \\
\hline Health status (\%) & \\
\hline Good & 40.21 \\
\hline Very good & 31.45 \\
\hline & 18.38 \\
\hline Poor & 2.73 \\
\hline Excellent & 2.73 \\
\hline Education (\%) & \\
\hline Some college/trade school & 41.88 \\
\hline College graduate & 20.95 \\
\hline High school graduate & 18.29 \\
\hline Postgraduate degree & 11.01 \\
\hline Some high school & 6.19 \\
\hline Grade school & 1.68 \\
\hline Work Status (\%) & \\
\hline Full-time & 52.76 \\
\hline Retired & 23.84 \\
\hline Not seeking employment & 11.04 \\
\hline Part-time & 9.63 \\
\hline Unemployed & 2.72 \\
\hline Disease condition (\%) & \\
\hline High b & 24.36 \\
\hline Arthritis, muscle or back pain & 13.81 \\
\hline Diabetes & 8.08 \\
\hline Heart problems & 7.52 \\
\hline otting & 2.28 \\
\hline
\end{tabular}




\section{Models}

Treating patient satisfaction with pharmacy services as exogenous, i.e. not correlated with error term, a single-equation probit model was used to estimate the relation between patient satisfaction and medication adherence. Because of the omitted variables and two-way causality, patient satisfaction is correlated with error term in single-equation probit model and thus violates the assumption of unbiased estimator. To address the endogeneity bias, bivariate probit models were subsequently employed using different sets of instrumental variables. Bivariate probit models simultaneously estimated the equations for the dependent variable (adherence) and the endogenous explanatory variable (patient satisfaction with pharmacy services). Because of the non-linear nature of the probit model, the 2-step procedure common in linear models (estimate the instrumental variable regression for the endogenous variable in the first stage and use the fitted value of the endogenous variable in the second stage) could not be used. The bivariate probit model is an appropriate model to use when the dependent variable and the endogenous explanatory variable are dichotomous. In the presence of endogeneity problems, the bivariate probit model gives asymptotically unbiased, consistent and efficient estimates. ${ }^{23,24}$

The single-equation model with exogenous patient satisfaction was estimated as:

adherence $_{i}=\gamma_{0}+\gamma_{1}\left(\right.$ satisfaction $\left._{i}\right)+\gamma_{2}\left(\mathrm{X}_{\mathrm{i}}\right)+\eta$

Where

adherence $_{i}=\left\{\begin{array}{l}1 \text { if patient } i \text { adhere to medicatoin recommendations } \\ 0 \text { otherwise }\end{array}\right.$

In terms of the data generating process, adherence was the dichotomous outcome of interest. Patient satisfaction was treated as the dichotomous exogenous regressor in the single-equation probit model and $X_{i}$ was a vector of other exogenous covariates determining medication adherence.

The bivariate probit model is the 2-equation endogenous satisfaction model. The first-stage equation is specified as:

$$
\begin{aligned}
& \text { satisfaction }_{i} *=\alpha_{0}+\alpha_{1}\left(\mathrm{IV}_{\mathrm{i}}\right)+\alpha_{2}\left(\mathrm{X}_{\mathrm{i}}\right)+\varepsilon_{1} \\
& \text { satisfaction }_{i}=1\left(\text { satisfaction }_{i} *>0\right)
\end{aligned}
$$

The second-stage equation is specified as:

$$
\text { adherence }_{i}^{*}=\beta_{0}+\beta_{1}\left(\text { satisfaction }_{i}\right)+\beta_{2}\left(\mathrm{X}_{\mathrm{i}}\right)+\varepsilon_{2}
$$

$$
\text { adherence }_{i}=1\left(\text { adherence }_{i}{ }^{*}>0\right)
$$

Where $X_{i}$ is the vector of other exogenous covariates. We assume $\varepsilon 1$ and $\varepsilon 2$ are serially independent and identically distributed (i.i.d) bivariate normal variables (BVN) and have the following distribution:

$$
\left(\begin{array}{l}
\varepsilon_{1} \\
\varepsilon_{2}
\end{array}\right) \sim B V N\left(\left(\begin{array}{l}
0 \\
0
\end{array}\right),\left[\begin{array}{ll}
1 & \rho \\
\rho & 1
\end{array}\right]\right)
$$

The instrumental variables used in the first-stage equation (2) were different combinations of the 3 instrumental variables discussed above. This is a recursive simultaneous binary choice model and the two equations are estimated simultaneously using the Maximum Likelihood method. ${ }^{24}$

Rho $(\rho)$ is the correlation coefficient that measures the residual association between the two equations. A Wald test of the significance of $\rho$ is a direct test of the endogeneity of patient satisfaction. ${ }^{24}$ The null hypothesis is that $\rho$ equals zero and it is appropriate to use the univariate (single-equation) probit model. If $\rho$ is significantly different from zero then medication adherence is not only directly affected by patient satisfaction but also indirectly influenced through other latent omitted factors, hence, justifying the use of bivariate probit models.

The magnitude of the patient satisfaction effect is our primary concern mainly because the coefficient estimates from a binary choice model can be misleading. As Greene (1998) pointed out "the absolute scale of the coefficients gives a distorted picture of the response of the dependent variable to a change in one of the stimuli". ${ }^{23}$ The reported marginal effects in this study are the combined effects that consist of an indirect effect generated by the equation (2), as well as a direct effect produced by the equation (3). The instrumental variables enter the satisfaction equation (2), which influences the probability that the patient is satisfied with pharmacy services.

For a continuous independent variable, the marginal effect assesses how one unit change in the independent variable influences the dependent variable. For a binary independent variable, the marginal effect evaluates how a discrete change from 0 to 1 affects the outcome probability for the dependent variable (e.g., medication adherence). The analytical form is exceedingly complicated and most software including STATA uses numerical approximation to compute the derivatives and standard errors. The standard error is calculated using the delta method for the asymptotic estimator of variance. The analytical expression of the marginal effect and detailed illustration on the delta method can be found in Greene (2003) and Christofides (1997). ${ }^{23,34}$

\section{Specification Test}

We used the Smith-Blundell test of exogeneity to test the null hypothesis that patient satisfaction is e exogenous. ${ }^{35}$ The test statistic is evaluated with respect to a chi-square distribution and the associated p-values. A rejection of the null hypothesis validates that patient satisfaction is endogenous. Sargan and Basmann overidentification tests were employed to test the null hypothesis that the excluded instruments are valid exclusions, i.e. they are uncorrelated with the error term and correctly excluded from the main estimation equation. ${ }^{36,37}$ In addition, being valid is 
one of the requirements for the instrumental variables. Another requirement is that they must have high explanatory powers. In other words, weak instruments can result in biased instrumental variable estimates. ${ }^{21}$ The Staiger \& Stock $(1997)^{38}$ weak instrument test is then used to test the strength of explanatory power of the instrumental variables. The null hypothesis is that the instrumental variables are jointly insignificant and a rejection of the null indicates that the selected instrumental variables have strong explanatory power for the endogenous variables.

\section{Statistical test}

SAS 9.1 was used to extract the study intake population. STATA 9.0 was used for executing all descriptive and statistical analyses. Regression coefficient estimates as well as marginal effects for selected variables were reported. Robust standard errors were computed for bivariate probit models given the possibility of heteroskedasticity induced by the selection bias.

\section{RESULTS}

Table 1 summarizes demographic characteristics for the study population. The mean age was about 51 years with $64 \%$ being female patients. About $58 \%$ of the patients were white and $65 \%$ of the patients were married. Over $70 \%$ indicated they had good or very good overall health status. Around $42 \%$ had some college education and $21 \%$ completed college degree. More than half $(53 \%)$ of the patients had full-time jobs. With regard to patients' health status, about $24 \%$ were high blood pressure, $14 \%$ had arthritis or back pain problems, $8 \%$ had diabetes and approximately $8 \%$ had cardiovascular problems.

\begin{tabular}{|c|c|c|c|c|c|c|c|c|c|c|}
\hline \multirow{3}{*}{ Tests } & \multicolumn{10}{|c|}{ Combinations of instrumental variables } \\
\hline & \multicolumn{2}{|c|}{$\begin{array}{c}\text { Non KP } \\
\text { pharmacy use }\end{array}$} & \multicolumn{2}{|c|}{$\begin{array}{l}\text { Happy + non KP } \\
\text { pharmacy use }\end{array}$} & \multicolumn{2}{|c|}{$\begin{array}{l}\text { Calm + non KP } \\
\text { pharmacy use }\end{array}$} & \multicolumn{2}{|c|}{ Happy + Calm } & \multicolumn{2}{|c|}{$\begin{array}{l}\text { Happy + Calm + non } \\
\text { KP pharmacy use }\end{array}$} \\
\hline & Stats & P-value & Stats & P-value & Stats & $P$-value & Stats & P-value & Stats & P-value \\
\hline $\begin{array}{l}\text { Smith-Blundell } \\
\text { test of exogeneity }\end{array}$ & 6.553 & 0.011 & 22.907 & $<0.001$ & 28.324 & $<0.001$ & 26.976 & $<0.001$ & 31.376 & $<0.001$ \\
\hline $\begin{array}{l}\text { Sargan } \\
\text { Over Identification Test }\end{array}$ & $--^{*}$ & -- & 0.528 & 0.468 & 0.759 & 0.384 & 0.060 & 0.806 & 0.703 & 0.704 \\
\hline $\begin{array}{l}\text { Basmann } \\
\text { Over Identification Test }\end{array}$ & $--^{*}$ & -- & 0.525 & 0.469 & 0.755 & 0.385 & 0.060 & 0.807 & 0.699 & 0.705 \\
\hline $\begin{array}{l}\text { Staiger-Stock } \\
\text { Weak Instrument Test }\end{array}$ & 24.710 & $<0.001$ & 24.450 & $<0.001$ & 26.400 & $<0.001$ & 19.740 & $<0.001$ & 19.480 & $<0.001$ \\
\hline
\end{tabular}

Table 2 gives the model specification test results on the instrumental variables. The Smith-Blundell test of exogeneity gives significant test results on all combinations of instrumental variables $(p<0.011)$, indicating a rejection of the null hypothesis that patient satisfaction is exogenous. Thus patient satisfaction should be treated as endogenous variable and instrumental variable method should be adopted. Both Sargan and Basmann overidentification tests failed to reject the null hypothesis for all five different combinations of the instrumental variables $(p>0.05)$. Thus we conclude that the selected instrumental variables are valid and justifiably excluded from the main equation estimations. The Staiger-Stock weak instrument test gave significant results $(p<0.001)$ suggest that the instrumental variables are jointly significant. This means that there was sufficient explanatory power of the instrumental variables used. All tests are indicative that the instrumental variables are strongly correlated with patient satisfaction.

The model estimations of the pharmacist consultation effectiveness were given in Table 3 with estimated results from both the single equation probit model (column 1) and the bivariate probit models (column 2 to column 6). Robust standard errors are reported in parentheses. We found that correlation coefficients $(\rho)$ were significantly different from zero for all bivariate probit models. Hence, we are able to reject the null hypothesis and confirm the simultaneous estimation approach under the bivariate probit models.

Table 4 exhibits the marginal effects from the model estimation. Similar to Table 3, column 1 gives the marginal effects estimated by the single equation probit model and column 2 to column 6 gives the results estimated by the bivariate probit models. The significant and positive marginal effects of patient satisfaction with pharmacist consultation service were found under both the single equation probit and bivariate probit models, reflecting a positive association between patient satisfaction and medication adherence, as hypothesized. Further, the magnitude of the effect differs significantly between the single equation probit and bivariate probit models. The single equation probit model reported a marginal effect of $0.07 \quad(p<0.01)$ for patient satisfaction with pharmacist consultation service on medication adherence, reflecting that the likelihood of a $7 \%$ increase in medication adherence for a satisfied patient with average values for all explanatory variables. Under the bivariate probit models, the marginal effect of patient satisfaction ranged from $0.20 \quad(p<0.05)$ to $0.30 \quad(p<0.01)$, reflecting that a satisfied patient increases the likelihood of adherence $20 \%$ to $30 \%$ once the endogeneity is corrected for. This result is statistically significant since the marginal effect under the single equation probit fell outside of the $95 \% \mathrm{Cl}(0.07 \pm 1.96$ (0.013), see Table 4). We obtained similar marginal effects of patient 
satisfaction across models using five different sets of instrumental variables. This outcome provides strong evidence of the robustness of the model and the validity of the instrumental variables selected.

\begin{tabular}{|c|c|c|c|c|c|c|}
\hline \multirow[t]{2}{*}{ Variables } & \multirow{2}{*}{$\begin{array}{l}\text { Single-equation } \\
\text { Probit Model }\end{array}$} & \multicolumn{5}{|c|}{ Bivariate Probit Models } \\
\hline & & $\begin{array}{c}\text { non KP pharmacy } \\
\text { use }\end{array}$ & $\begin{array}{l}\text { Happy + non KP } \\
\text { pharmacy use }\end{array}$ & $\begin{array}{l}\text { Calm + non KP } \\
\text { pharmacy use }\end{array}$ & Happy + Calm & $\begin{array}{c}\text { Happy + Calm + } \\
\text { non KP pharmacy } \\
\text { use }\end{array}$ \\
\hline Patient satisfaction & $0.183^{\star * *}(0.035)$ & $0.753^{\star * *}(0.285)$ & $1.021^{\star \star \star}(0.151)$ & $1.095^{\star \star *}(0.136)$ & $1.067^{\star \star \star}(0.145)$ & $1.102^{\star \star \star}(0.128)$ \\
\hline Age & $0.015^{\star \star \star}(0.002)$ & $0.012^{\star * \star}(0.003)$ & $0.010^{\star \star \star}(0.002)$ & $0.009^{* \star *}(0.002)$ & $0.009^{* * *}(0.002)$ & $0.009^{\star \star \star}(0.002)$ \\
\hline Gender (female) & $-0.053(0.037)$ & $-0.065^{*}(0.037)$ & $-0.072^{\star *}(0.036)$ & $-0.068^{*}(0.036)$ & $-0.069 *(0.036)$ & $-0.069 *(0.036)$ \\
\hline $\begin{array}{r}\text { Race } \\
\text { White } \\
\text { Black } \\
\text { Other race }\end{array}$ & $\begin{array}{c}0.093(0.132) \\
-0.026(0.135) \\
-0.022(0.135)\end{array}$ & $\begin{array}{c}0.039(0.133) \\
-0.074(0.135) \\
-0.012(0.135)\end{array}$ & $\begin{array}{l}-0.001(0.129) \\
-0.106(0.132) \\
-0.021(0.132)\end{array}$ & $\begin{array}{l}-0.01(0.130) \\
-0.112(0.132) \\
-0.028(0.133)\end{array}$ & $\begin{array}{l}-0.007(0.129) \\
-0.109(0.131) \\
-0.038(0.132)\end{array}$ & $\begin{array}{l}-0.031(0.130) \\
-0.135(0.133) \\
-0.049(0.133)\end{array}$ \\
\hline $\begin{array}{r}\text { Education } \\
\text { High school } \\
\text { Some college } \\
\text { College }\end{array}$ & $\begin{array}{l}-0.321(0.301) \\
-0.376(0.301) \\
-0.348(0.301)\end{array}$ & $\begin{array}{l}-0.375(0.316) \\
-0.422(0.316) \\
-0.344(0.318)\end{array}$ & $\begin{array}{l}-0.363(0.315) \\
-0.401(0.315) \\
-0.313(0.316)\end{array}$ & $\begin{array}{l}-0.359(0.316) \\
-0.395(0.315) \\
-0.296(0.316)\end{array}$ & $\begin{array}{l}-0.312(0.304) \\
-0.347(0.304) \\
-0.261(0.304)\end{array}$ & $\begin{array}{l}-0.352(0.315) \\
-0.387(0.315) \\
-0.291(0.316)\end{array}$ \\
\hline $\begin{array}{r}\text { Marital status } \\
\text { Single } \\
\text { Married } \\
\text { Separated } \\
\text { Divorced } \\
\text { Widowed }\end{array}$ & $\begin{array}{l}0.386(0.242) \\
0.381(0.238) \\
0.359(0.256) \\
0.247(0.242) \\
0.318(0.247)\end{array}$ & $\begin{array}{l}0.463^{*}(0.278) \\
0.480^{*}(0.275) \\
0.433(0.291) \\
0.318(0.278) \\
0.447(0.286)\end{array}$ & $\begin{array}{l}0.480^{*}(0.274) \\
0.497^{\star}(0.271) \\
0.462(0.286) \\
0.328(0.274) \\
0.475^{\star}(0.28)\end{array}$ & $\begin{array}{l}0.464(0.283) \\
0.480^{*}(0.28) \\
0.430(0.295) \\
0.311(0.283) \\
0.449(0.289)\end{array}$ & $\begin{array}{l}0.397(0.277) \\
0.409(0.274) \\
0.376(0.289) \\
0.243(0.277) \\
0.365(0.283)\end{array}$ & $\begin{array}{l}0.466^{*}(0.283) \\
0.484^{*}(0.280) \\
0.436(0.295) \\
0.314(0.283) \\
0.458(0.289)\end{array}$ \\
\hline $\begin{array}{r}\text { Work status } \\
\text { Full-time } \\
\text { Part-time } \\
\text { Unemployed } \\
\text { Retired } \\
\text { Not seeking } \\
\end{array}$ & $\begin{array}{c}-0.133^{\star *}(0.059) \\
-0.076(0.075) \\
-0.045(0.113) \\
-0.008(0.075) \\
0.053(0.102) \\
\end{array}$ & $\begin{array}{l}-0.125^{\star \star}(0.061) \\
-0.090(0.074) \\
-0.041(0.110) \\
-0.031(0.074) \\
0.002(0.107) \\
\end{array}$ & $\begin{array}{l}-0.103^{*}(0.059) \\
-0.081(0.073) \\
-0.035(0.108) \\
-0.032(0.073) \\
-0.027(0.104) \\
\end{array}$ & $\begin{array}{l}-0.097^{\star}(0.059) \\
-0.073(0.073) \\
-0.028(0.107) \\
-0.025(0.072) \\
-0.032(0.105)\end{array}$ & $\begin{array}{l}-0.086(0.058) \\
-0.063(0.072) \\
-0.031(0.105) \\
-0.009(0.071) \\
-0.038(0.103)\end{array}$ & $\begin{array}{l}-0.094(0.059) \\
-0.074(0.073) \\
-0.026(0.107) \\
-0.022(0.072) \\
-0.032(0.104)\end{array}$ \\
\hline $\begin{array}{r}\text { Health status } \\
\text { General } \\
\text { Arthritis /back pain } \\
\text { Diabetes } \\
\text { High blood press. } \\
\text { Seizure disorder } \\
\text { Heart problem } \\
\text { Blood clotting }\end{array}$ & $\begin{array}{c}-0.065^{\star *}(0.026) \\
-0.273^{\star \star *}(0.048) \\
0.336^{\star \star *}(0.067) \\
0.325^{* \star *}(0.042) \\
0.814^{* \star *}(0.221) \\
0.249^{\star * *}(0.073) \\
0.064(0.126)\end{array}$ & $\begin{array}{c}-0.048^{*}(0.029) \\
-0.265^{\star \star *}(0.049) \\
0.315^{\star \star *}(0.068) \\
0.305^{\star \star *}(0.044) \\
0.779^{\star * *}(0.204) \\
0.201^{\star * *}(0.076) \\
0.060(0.124)\end{array}$ & $\begin{array}{c}-0.038(0.027) \\
-0.259^{\star \star *}(0.048) \\
0.288^{\star \star *}(0.066) \\
0.286^{\star \star *}(0.043) \\
0.727^{\star * *}(0.195) \\
0.170^{\star *}(0.072) \\
0.046(0.120)\end{array}$ & $\begin{array}{c}-0.026(0.027) \\
-0.257^{\star \star *}(0.047) \\
0.294^{\star \star *}(0.065) \\
0.275^{\star \star *}(0.042) \\
0.720^{\star * *}(0.194) \\
0.171^{\star *}(0.071) \\
0.065(0.120)\end{array}$ & $\begin{array}{c}-0.028(0.027) \\
-0.259^{\star \star \star}(0.047) \\
0.300^{\star \star *}(0.065) \\
0.281^{\star \star *}(0.042) \\
0.722^{\star * \star}(0.195) \\
0.175^{\star *}(0.071) \\
0.054(0.118)\end{array}$ & $\begin{array}{c}-0.030(0.027) \\
-0.260^{* * \star}(0.047) \\
0.289^{\star \star *}(0.065) \\
0.276^{\star \star *}(0.042) \\
0.716^{\star * *}(0.193) \\
0.169^{\star *}(0.071) \\
0.054(0.119)\end{array}$ \\
\hline $\begin{array}{l}\text { How to take } \\
\text { medication }\end{array}$ & $-0.167^{\star * \star}(0.037)$ & $-0.243^{\star * *}(0.049)$ & $-0.272^{\star \star \star}(0.039)$ & $-0.279^{\star \star \star}(0.038)$ & $-0.268^{* \star *}(0.039)$ & $-0.279^{\star \star \star}(0.038)$ \\
\hline Constant & $-0.671^{*}(0.349)$ & $-0.805^{\star *}(0.383)$ & $-0.858^{\star *}(0.370)$ & $-0.899^{\star *}(0.372)$ & $-0.844^{\star *}(0.351)$ & $-0.858^{* \star}(0.371)$ \\
\hline Observations & 6662 & 6529 & 6461 & 6461 & 6543 & 6414 \\
\hline $\begin{array}{l}\text { Disturbance } \\
\text { correlation, } \rho\end{array}$ & & $-0.368^{*}(0.202)$ & $-0.582^{\star \star *}(0.131)$ & $-0.650^{* \star *}(0.128)$ & $-0.622^{* * *}(0.133)$ & $-0.659^{* * *}(0.122)$ \\
\hline Log likelihood & -4044.862 & -7916.132 & -7819.802 & -7777.899 & -7946.915 & -7749.045 \\
\hline
\end{tabular}

In addition, other significant marginal effects were found for age, full-time employment status and disease conditions. Specifically, older patients are more likely to adhere to their medications since a one year increase in age increases the likelihood of being adherent by 0.6 to 0.7 percent $(p<0.01)$. This result is consistent with previous published study that older patients have a higher incident of adhering to medications.20, 39 Further, for a satisfied fully employed patient, the likelihood of medication adherence is decreased by $4 \%-5 \%$ as compared to a satisfied but not fully employed patient $(p<0.05)$. Moreover, satisfied patients with life-threatening chronic conditions such as diabetes, high blood pressure, heart problems and seizure disorder are more likely to adhere to their medications as compared to satisfied patients without life-threatening chronic health conditions. The magnitude of increase in the likelihood of medication adherence ranged from $8 \%-17 \%$ $(p<0.01)$. Contrariwise, satisfied patients with manageable chronic conditions such as arthritis or back pain are about $8 \%$ less likely to adhere to their medications $(p<0.01)$. These findings imply that the severity of illness has significant effect on patient medication adherence. Patients with manageable chronic health conditions seem to place medication adherence on a lower priority level compared to patients with more severe diseases. Furthermore, satisfied patients who received instructional help from the pharmacist on how to take their medications tend to be $2 \%-3 \%$ more likely to adhere $(p<0.1)$ under the bivariate probit models. On the contrary, such patients were about $6 \%$ less likely to adhere under the single equation probit model. These rather counter-intuitive results are, perhaps, indicative of the presence of endogeneity bias. Patient satisfaction with pharmacist consultation is likely to be correlated with this "howto" variable. When patient satisfaction is treated as 
an exogenous variable, this correlation will cause downward bias of the coefficient for this "how-to" variable, i.e. making it more negative. When endogeneity is corrected, this correlation is mitigated and the downward bias is also corrected.

\begin{tabular}{|c|c|c|c|c|c|c|}
\hline \multirow[t]{2}{*}{ Variables } & \multirow{2}{*}{$\begin{array}{l}\text { Single-equation } \\
\text { Probit Model }\end{array}$} & \multicolumn{5}{|c|}{ Bivariate Probit Models } \\
\hline & & $\begin{array}{c}\text { non KP } \\
\text { pharmacy use }\end{array}$ & $\begin{array}{l}\text { Happy + non KP } \\
\text { pharmacy use }\end{array}$ & $\begin{array}{l}\text { Calm + non KP } \\
\text { pharmacy use }\end{array}$ & Happy + Calm & $\begin{array}{c}\text { Happy + Calm + } \\
\text { non KP pharmacy } \\
\text { use }\end{array}$ \\
\hline Satisfaction & $0.069^{\star \star \star}(0.013)$ & $0.199^{\star *}(0.08)$ & $0.275^{\star \star \star}(0.042)$ & $0.296^{\star \star *}(0.038)$ & $0.287^{\star \star \star}(0.041)$ & $0.298^{\star \star \star}(0.036)$ \\
\hline Age & $0.006^{\star \star *}(0.001)$ & $0.007^{\star * \star}(0.001)$ & $0.007^{\star * *}(0.001)$ & $0.006^{\star \star *}(0.001)$ & $0.006^{\star \star *}(0.001)$ & $0.006^{\star \star \star}(0.001)$ \\
\hline Gender (female) & $-0.02(0.014)$ & $0.005(0.012)$ & $0.003(0.012)$ & $0.007(0.012)$ & $0.004(0.012)$ & $0.006(0.012)$ \\
\hline $\begin{array}{r}\text { Race } \\
\text { White } \\
\text { Black } \\
\text { Other race } \\
\end{array}$ & $\begin{array}{c}0.035(0.050) \\
-0.010(0.051) \\
-0.008(0.051) \\
\end{array}$ & $\begin{array}{c}0.053(0.045) \\
0.012(0.046) \\
-0.026(0.046)\end{array}$ & $\begin{array}{c}0.043(0.044) \\
-0.0001(0.045) \\
-0.035(0.044)\end{array}$ & $\begin{array}{c}0.045(0.044) \\
-0.001(0.045) \\
-0.035(0.044)\end{array}$ & $\begin{array}{c}0.044(0.043) \\
0.0004(0.044) \\
-0.037(0.044) \\
\end{array}$ & $\begin{array}{c}0.040(0.044) \\
-0.007(0.045) \\
-0.041(0.044)\end{array}$ \\
\hline $\begin{array}{r}\text { Education } \\
\text { High school } \\
\text { Some college } \\
\text { college }\end{array}$ & $\begin{array}{l}-0.123(0.117) \\
-0.142(0.113) \\
-0.132(0.116) \\
\end{array}$ & $\begin{array}{l}-0.068(0.087) \\
-0.088(0.087) \\
-0.118(0.085) \\
\end{array}$ & $\begin{array}{l}-0.070(0.085) \\
-0.088(0.085) \\
-0.117(0.083) \\
\end{array}$ & $\begin{array}{l}-0.071(0.084) \\
-0.091(0.084) \\
-0.119(0.082) \\
\end{array}$ & $\begin{array}{l}-0.056(0.082) \\
-0.074(0.082) \\
-0.106(0.080)\end{array}$ & $\begin{array}{l}-0.067(0.084) \\
-0.085(0.084) \\
-0.114(0.083)\end{array}$ \\
\hline $\begin{array}{r}\text { Marital status } \\
\text { Single } \\
\text { Married } \\
\text { Separated } \\
\text { Divorced } \\
\text { Widowed } \\
\end{array}$ & $\begin{array}{l}0.135(0.078) \\
0.145(0.091) \\
0.124(0.080) \\
0.089(0.083) \\
0.112(0.081)\end{array}$ & $\begin{array}{l}0.010(0.088) \\
0.029(0.084) \\
-0.007(0.094) \\
-0.007(0.088) \\
-0.047(0.088)\end{array}$ & $\begin{array}{l}0.013(0.090) \\
0.030(0.084) \\
0.009(0.096) \\
-0.006(0.089) \\
-0.050(0.089)\end{array}$ & $\begin{array}{l}-0.028(0.084) \\
-0.002(0.081) \\
-0.034(0.089) \\
-0.046(0.082) \\
-0.087(0.081)\end{array}$ & $\begin{array}{l}0.002(0.081) \\
0.010(0.078) \\
0.001(0.087) \\
-0.016(0.080) \\
-0.060(0.079)\end{array}$ & $\begin{array}{l}-0.028(0.085) \\
-0.003(0.082) \\
-0.030(0.091) \\
-0.045(0.084) \\
-0.091(0.082)\end{array}$ \\
\hline $\begin{array}{r}\text { Work status } \\
\text { Full-time } \\
\text { Part-time } \\
\text { Unemployed } \\
\text { Retired } \\
\text { Not seeking }\end{array}$ & $\begin{array}{l}-0.050^{* *}(0.022) \\
-0.029(0.028) \\
-0.017(0.043) \\
-0.003(0.028) \\
0.020(0.037)\end{array}$ & $\begin{array}{c}-0.055^{* * *}(0.020) \\
-0.023(0.024) \\
-0.014(0.037) \\
0.002(0.025) \\
0.075^{* *}(0.035)\end{array}$ & $\begin{array}{c}-0.049^{* *}(0.019) \\
-0.018(0.024) \\
-0.008(0.036) \\
0.008(0.025) \\
0.079^{* *}(0.035)\end{array}$ & $\begin{array}{c}-0.048^{* *}(0.019) \\
-0.014(0.024) \\
-0.009(0.036) \\
0.010(0.025) \\
0.086^{* *}(0.035)\end{array}$ & $\begin{array}{c}-0.042^{\star *}(0.019) \\
-0.009(0.023) \\
-0.008(0.035) \\
0.023(0.025) \\
0.083^{* *}(0.035)\end{array}$ & $\begin{array}{c}-0.047^{* *}(0.019) \\
-0.016(0.024) \\
-0.007(0.036) \\
0.013(0.025) \\
0.088^{\star *}(0.035)\end{array}$ \\
\hline $\begin{array}{r}\text { Health status } \\
\text { General } \\
\text { Arthritis / back pain } \\
\text { Diabetes } \\
\text { High blood press. } \\
\text { Seizure disorder } \\
\text { Heart problem } \\
\text { Blood clotting } \\
\end{array}$ & $\begin{array}{c}-0.024^{\star *}(0.010) \\
-0.105^{\star \star *}(0.019) \\
0.118^{\star \star *}(0.022) \\
0.117^{\star \star *}(0.015) \\
0.241^{* \star *}(0.045) \\
0.089^{\star * *}(0.025) \\
0.024(0.046)\end{array}$ & $\begin{array}{c}-0.035^{\star \star \star *}(0.009) \\
-0.074^{\star \star *}(0.016) \\
0.087^{\star * *}(0.022) \\
0.088^{\star * *}(0.014) \\
0.155^{\star \star}(0.072) \\
0.109^{\star * *}(0.026) \\
0.032(0.045)\end{array}$ & $\begin{array}{c}-0.028^{\star \star *}(0.009) \\
-0.077^{\star * *}(0.015) \\
0.083^{\star * *}(0.022) \\
0.086^{\star * *}(0.014) \\
0.176^{\star *}(0.073) \\
0.102^{\star * *}(0.027) \\
0.031(0.045) \\
\end{array}$ & $\begin{array}{c}-0.024^{\star * \star}(0.009) \\
-0.078^{* \star *}(0.015) \\
0.078^{\star * *}(0.022) \\
0.086^{\star \star *}(0.014) \\
0.171^{\star *}(0.072) \\
0.108^{\star * *}(0.027) \\
0.024(0.045)\end{array}$ & $\begin{array}{c}-0.021^{* *}(0.009) \\
-0.078^{\star * *}(0.015) \\
0.079^{\star * *}(0.022) \\
0.086^{* \star *}(0.014) \\
0.17^{* *}(0.073) \\
0.102^{\star * *}(0.026) \\
0.020(0.045)\end{array}$ & $\begin{array}{c}-0.023^{* *}(0.009) \\
-0.079^{\star * *}(0.015) \\
0.078^{\star * \star}(0.022) \\
0.086^{\star \star *}(0.014) \\
0.172^{\star *}(0.072) \\
0.103^{\star * \star}(0.027) \\
0.027(0.045)\end{array}$ \\
\hline $\begin{array}{l}\text { How to take } \\
\text { medication }\end{array}$ & $-0.063^{* * *}(0.014)$ & $0.030^{\star *}$ & $0.024^{*}(0.013)$ & 0.0 & $0.023^{*}(0$ & $0.023^{*}(0.013)$ \\
\hline Observations & 6662 & 6529 & 6461 & 6434 & 6543 & 6414 \\
\hline
\end{tabular}

\section{DISCUSSION}

Although the single equation probit model exhibited a significant positive effect of patient satisfaction with pharmacist consultation on patient medication adherence, it underestimated the magnitude of this effect. Bivariate probit models showed that the magnitude of the effect of patient satisfaction with pharmacist consultation on medication adherence was substantially greater. The marginal effect statistically significantly increased from about 0.07 to as much as 0.30 after correcting for endogeneity bias $(p<0.01)$ indicating that for a satisfied patient, the likelihood of being adherent to his/her medication, relative to an unsatisfied patient, can be more than 4-fold when estimated with the bivariate probit model. This finding is relevant to targeting and evaluating the effectiveness of pharmacist consultation services

In this study, we have demonstrated a successful application of the IV method for correcting endogeneity bias in patient self-reported satisfaction with pharmacist consultation services. The approach used in this study is applicable when dichotomous dependent and endogenous regressors are present. In addition to a methodological contribution, this research also provides important policy implications. Both healthcare professionals and patients recognize the importance of pharmacist consultation. The function of pharmacists has evolved from drug dispensing to a more active role of information sharing, risk management and other consultation. This change has been documented by the 2003 Medicare Modernization Act and the 2004 Joint Commission of Pharmacy Practitioners. Several studies $4,17,40$ have found that there is a disagreement between patients and pharmacists on the appropriate role of the pharmacist. For instance, patients may not view pharmacists as a resource for drug-related risk management or for long-term healthcare issues, while more and more pharmacists are taking upon a more active role in patient healthcare management. On the other hand, some patients' concerns are not adequately addressed by the pharmacists. Patients may have concerns over the costs of their 
medications, especially for patients of low-income, no health insurance, or insurance with deductibles. Pharmacists may address these concerns by providing advice on medication management or generic drug alternatives with similar clinical results. The discrepancy between patients' expectations and the new role of pharmacists can affect the overall patient satisfaction with pharmacist consultation. Recent studies suggested several channels to help both parties to agree on their roles and expectations of the other. One suggestion is through patient education and collaborative efforts of other healthcare providers, especially physicians, so that patients can be better informed and can expect more help from the pharmacists. ${ }^{4,5}$ These interactions may improve understanding between pharmacists and the patients and lead to higher patient satisfaction level.

Certain study limitations should be mentioned. First, in this paper it is not directly analyzed how pharmacists can improve patient satisfaction because "satisfaction" in this survey is an aggregate measure. This problem should be studied in future research when factors influencing patient satisfactions are disaggregated into detailed components.

Second, although prior study has shown that selfreported medication adherence is correlated with actual adherence recorded by more objective measures, adherence measurement may, to some extent, bias our results. ${ }^{28}$ Therefore, the next step of the research in this area is to merge patient satisfaction survey and other demographic and clinical information with pharmacy patient medication reports or other objective measurements of patient medication adherence. Third, ceiling effects in both the dichotomized dependent variable (medication adherence) and the endogenous regressor (patient satisfaction) may have reduced variation in the underlying ordinal rating scales. Fourth, as we focus on the hypothesis with regard to pharmacist consultation, there may still be other important variables that were either not available or not included in our model specification. For example, pharmacists' technical capability, pharmacist courtesy, pharmacy convenience or, physician services, etc., could also be correlated with patient satisfaction. Fifth, the results should be interpreted with appropriate caveats because of omitted variables. For example, we did not control for drugs or drug types in the study. Hence, some findings such as older patients are more likely to adhere their medications may also imply that these patients may be on drugs that are for maintenance purposes for chronic health conditions. Sixth, the variable(s) used from the current instrument may not be the best or the most complete patient satisfaction survey with pharmacist consultation. The satisfaction in this study is an overall evaluation. In future studies, more detailed questions are needed to analyze how patients react to different aspects of pharmacist consultation including friendliness, professional manner, the information provided, waiting time, etc. ${ }^{41}$ Further, the sample patients are all members of a large managed care organization; hence, the findings in this study may not be fully generalizable to other health care settings. Finally, while instrumental variable estimation has many nice properties, it is often hard to identify a set of valid and strong instrumental variables in specific empirical studies.

\section{CONCLUSION}

Using a bivariate probit econometric model to appropriately adjust for endogeneity bias, this study supports previous researches that satisfied patients are more likely to adhere to their medications. The results have important policy implications given the increasing focus on the roles of pharmacists and regulatory changes in professional scope of practice. The results suggest that simple single equation specifications suffer from endogeneity bias due to either omitted variable bias or reversed causality. This study support the use of the instrumental variable approach in which the true magnitude of effect can be demonstrated by correcting potential endogeneity bias. The validity of our findings is supported by formal specification tests and evaluation of parameter sensitivity to different combinations of instrumental variables.

\section{CONFLICT OF INTEREST}

There is no financial support or conflict of interest associated with this paper.

\section{References}

1. Omnibus Budget Reconciliation Act of 1990 (42 U.S.C. 1396r-8). 101st Congress 2nd Session. Report 101-964.

2. Medicare Prescription Drug, Improvement and Modernization Act of 2003, Public Law 108-173-DEC. 8.

3. McCombs JS, Cody M, Besinque, K, Borok G, Ershoff D, Groshen S, Hay J, Johnson K, Nichol MB, Nye MT. Measuring the impact of patient counseling in the outpatient pharmacy setting: the research design of the Kaiser Permanente/USC patient consultation study. Clin. Ther. 1995; 17(6): 1188-1206.

4. Worley MM, Schommer JC, Brown LM, Hadsall RS, Ranelli PL, Stratton TP, Uden DL. Pharmacists' and patients' role in the pharmacist-patient relationship: are pharmacist and patients reading from the same relationship script? Res Soc Admin Pharm. 2007;3:47-69

5. Schommer JC, Pedersen CA, Worley MM, Brown LM, Hadsall RS, Ranelli PL, Stratton TP, Uden DL, Chewning BA. Provision of risk management and risk assessment information: the role of the pharmacist. Res Soc Admin Pharm. 2006;2:458-478.

6. Lonie JM. From counting and pouring to caring: the empathic developmental process of community pharmacists. Res Soc Admin Pharm. 2006;2:439-457. 
7. Lee JK, Grace KA, Taylor AJ. Effect of a pharmacy care program on medication adherence and persistence, blood pressure, and low-density lipoprotein cholesterol: a randomized controlled trial. JAMA. 2006;296(21):2563-2571.

8. McCombs JS, Liu G, Shi J, Feng W. Cody M, Parker JP, Nichol MB, Hay JW, Johnson KA, Groshen SL, Nye MT. Kaiser Permanente/USC patient consultation study: change in use and cost of health care services Am J Health-Syst Pharm. 1998; 55:2485-2499.

9. Yuan Y, Hay J, McCombs J. Mortality and hospitalization impacts of pharmacy consultation in ambulatory care. Amer $\mathrm{J}$ Manag Care. 2003;9(1):101-112.

10. Paulos CP, Nygren CEA, Celedon C, Carcamo C. Impact of pharmaceutical care program in a community pharmacy on patients with dyslipidemia. Ann Pharmacother. 2005;39:939-943.

11. Tsuyuki RT, Johnson JA, Teo KK, Simpson SH, Ackman ML, Biggs RS, Cave A, Chang WC, Dzavik V, Farris KB, Galvin D, Semchuk W, Taylor JG. For the Study of Cardiovascular Risk Intervention by Pharmacists (SCRIP) Investigators. A randomized trial of the effect of community pharmacist intervention of cholesterol risk management. Arch Intern Med. 2002;162:1149-1155.

12. Gerber RA, Liu G, McCombs, JS. Impact of pharmacist consultations provided to patients with diabetes on healthcare costs in a health maintenance organization. Am J Man Care. 1998;4:991-1000.

13. McLennan DN, Dooley MJ, Brien JE. Beneficial clinical outcomes resulting from pharmacist interventions. J Oncol Pharm Practice. 1999;5(4):184-189.

14. Jaber LA, Halapy H, Fernet M, Tummalapalli S, Diwakaran H. Evaluation of a pharmaceutical model in diabetes management. Ann Pharmacother. 1996;30(3):294-295.

15. Aharony L, Strasser S. Patient satisfaction: what we know about and what we still need to explore. Med Care Res Rev. 1993; 50: 49-79.

16. Renberg T, Lindblad AK, Tully MP. Exploring subjective outcomes perceived by patients receiving a pharmaceutical care service. Res Soc Admin Pharm. 2006;2:212-231.

17. Guirguis LM, Chewning BA. Role theory: literature review and implications for patient-pharmacist interactions. Res Soc Admin Pharm. 2005;1:483-507.

18. Oparah AC, Kikanme LC. Consumer satisfaction with community pharmacies in Warri, Nigeria. Res Soc Admin Pharm. 2006;2:499-511.

19. MacKinnon KJ, Swanson LS (Eds.) Striving beyond patient satisfaction: a road map for pharmacists. Inet Continuing Education. 2005; 9(9): www.InetCE.com [accessed on March 26, 2008].

20. Ownby RL. Medication adherence and cognition: medical, personal and economic factors influence level of adherence in older adults. The Psychiatric Consultant. 2006;61(2):30-35.

21. McClellan MB, Newhouse JP. Overview of the special supplement issue. Health Serv Res. 2000;35:1061-1069.

22. Newhouse JP, McClellan MB. Econometrics in outcomes research: the use of instrumental variables. Annual Review of Public Health. 1998;19:17-34.

23. Greene WH. Econometric Analysis (5th edition). Upper Saddle River, NJ: Prentice Hall, 2003.

24. Wooldridge JM. Econometric Analysis of Cross Section and Panel Data. MIT Press, Cambridge, MA, 2001.

25. Yoo BK, Frick KD. The instrumental variable method to study self-selection mechanism: a case of influenza vaccination. Value in Health. 2006;9(2):114-122.

26. Hay J. Appropriate econometric methods for pharmacoeconometric studies of retrospective claims data: an introductory guide. J Manag Care Pharm. 2005;11(4): 344-348.

27. Johnson KA, Nye M, Hill-Besinque K, Cody M. Measuring the impact of patient counseling in the outpatient pharmacy setting: development and implementation of the counseling models for the Kaiser Permanente/USC patient consultation study. Clin Ther. 1995;17(5):988-1002.

28. Hays RD, Kravitz RL, Mazel RM, Sherbourne CD, DiMatteo R, Rogers WH, Greenfield S. The impact of patient adherence on health outcomes for patients with chronic disease in the medical outcomes study. J Behav Med. 1994;17(4):346-360.

29. Kwon A, Bungay KM, Pei Y, Rogers WH, Wilson IB, Zhou Q, Adler DA. Antidepressant use: concordance between selfreport and claims records. Med Care. 2003;41:368-374.

30. Saunders K, Simon G, Bush T, Grothaus L. Assessing the feasibility of using computerized pharmacy refill data to monitor antidepressant treatment on a population basis: a comparison of automated and self-report data. J Clin Epidemiol. 1998; 51(10):883-890.

31. Rickles NM, Svarstad BL. Relationships between multiple self-reported nonadherence measures and pharmacy records. Res Soc Admin Pharm. 2007;3:363-377.

32. Johnson JA, Coons SJ, Hays RD, Pickard AS. Health status and satisfaction with pharmacy services. Am J Managed Care. 1999;5:163-170.

33. Cleary PD, McNeil BJ. Patient Satisfaction as an indicator of quality of care. Inquiry. 1988; 25: 25-36.

34. Christofides L, Stengos T, Swidinsky R. On the calculation of marginal effects in the bivariate probit model. Economics Letters, Elsevier, July 1997; 54(3): 203-208.

35. Smith RJ, Blundell RW. An exogeneity test for a simultaneous equation Tobit model with an application to labor supply. Econometrica. 1986; 54(3): 679-685.

36. Sargan JD. The estimation of economic relationships using instrumental variables. Econometrica. 1958; 26(3): 393-415.

37. Basmann RL. On finite sample distributions of generalized classical linear identifiability test statistics. Journal of the American Statistical Association. 1960; 55(292): 650-659.

38. Staiger D, Stock JH. Instrumental variables regression with weak instruments. Econometrica, 1997. 65(3):557-586. 
39. Gurwitz JH, Field TS, Harrold LR, Rothschild J, Debellis K, Seger AC, Cadoret C, Fish LS, Garber L, Kelleher M, Bates DW. Incidence and preventability of adverse drug events among older persons in the ambulatory setting. JAMA 2003; 289(9):1107-1116.

40. Brown LM, Schommer JC, Worley MM. Patient view of pharmacists' roles in health care: how similar are they to how pharmacists view themselves? Research in Social and Administrative Pharmacy 2007; 3: el0-e11.

41. Larson LN, MacKeigan LD. Further validation of an instrument to measure patient satisfaction with pharmacy services. $\mathrm{J}$ Pharm Mark Manage 1994; 8:125-140. 